\title{
楉類とカルボン酸塩を含むスケトウダラ冷凍すり身の 坐りゲル形成能
}

\author{
山本康博, 南部正一, 新井健一
}

(1991 年10月 17 日受付)

\author{
Gel Forming Ability of Walleye Pollack Frozen Surimi Containing \\ Sugar and Carboxylic Acid Salt \\ Yasuhiro Yamamoto, ${ }^{* 1}$ Shoichi Nanbu, ${ }^{* 1}$ and Ken-ichi Arai*2
}

\begin{abstract}
A new type of frozen surimi was prepared from walleye pollack upon addition of $5 \%$ sorbitol, $4 \%$ sucrose, $0.05 \%$ Ca-citrate, $0.05 \%$ Ca-lactate, $0.1 \% \mathrm{NaHCO}_{3}$, and $0.3 \%$ Napolyphosphate. By investigating myofibrillar $\mathrm{Ca}-\mathrm{ATPase}$ total activity of surimi and setting-gelforming ability along with cross-linking ability of myosin heavy chain of salt-ground meat from the same surimi, the quality of such frozen surimi was compared with that of standard frozen surimi, which contained $5 \%$ sorbitol, $4 \%$ sucrose, and $0.3 \%$ Na-polyphosphate.

The results showed that the rate of setting-gel formation together with that of crosslinking of myosin heavy chain were both enhanced in the case of salt-ground meat from the new type of surimi, while the mass in quality together with the quantity of myofibrillar protein in both types of surimi were practically identical.

It is thus evident that the quality of frozen surimi was considerably improved with the aid of new additives such as carboxylic acid salt, as mentioned above.
\end{abstract}

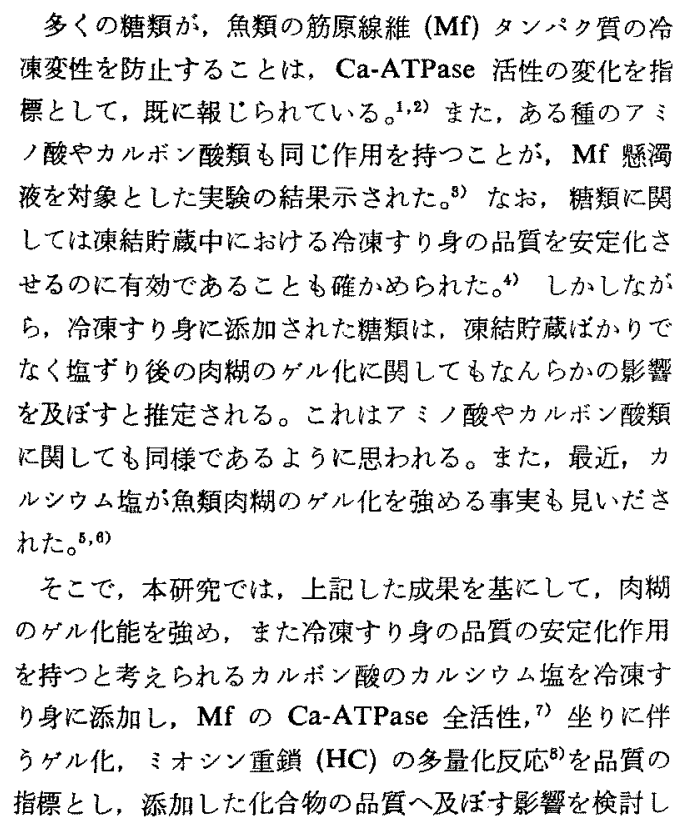

*1 東和化成工業株式会社 (Towa Chemical Industry Co., Ltd., Nakagawara, Fuji, Shizuoka 417, Japan).

*2 北海道大学水産学部食品学科生物化学䛶座 (Laboratory of Biochemistry, Department of Food Science, Faculty of Fisheries, Hokkaido University, Minato, Hakodate, Hokkaido 041, Japan). 
$\mathrm{ml}$ の $0.16 \mathrm{M} \mathrm{KCl}-40 \mathrm{~mm}$ Tris-maleate (pH 7.5) および $0.15 \mathrm{~m} / \infty 20 \%$ Triton X-100を加え, 冷却しながら 1 分間ナ゙つ6回ホモジナイズを繰り返した。6,000×gで10

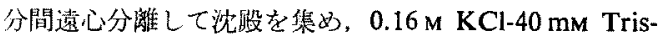
maleate (pH 7.5) を加之て挤找し, 賞心分雂する操作を 数回繰り返して洗海した。沈貶をがラス㹈ハンドホモジ ナイザーを用いて同上溶液に対して均質に㲘滀させ，全

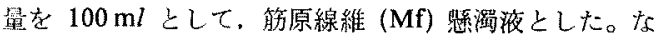

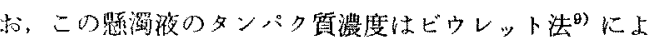
り比色定置した。また，Ca-ATPase (EC 3.6.1.3) は，5 mм $\mathrm{CaCl}_{2}, 0.1$ 焉大休 $0.5 \mathrm{M} \mathrm{KCl}, 25 \mathrm{~mm}$ Tris-maleate (pH 7.0), $1 \mathrm{mM}$ ATP および $0.2 \sim 0.3 \mathrm{mg} / \mathrm{m} / \mathrm{Mf}$ の反 応泿液中で $25^{\circ} \mathrm{C} て ゙ 反$ 応せて，生成した無譏りン酸を

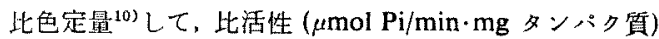
农求めた。

かまほこゲルの調制 泠凍すり身が完全に解凍しない らちに細切し，終䙉度で $2.5 \%$ の NaClを添加してスピ

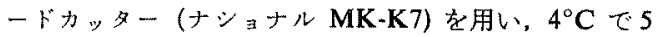
分間らいかいし，肉糊を調製した。国)この肉糊の気泡を 抜いた後にプラスチック製円筒型容器（值径 $3.7 \mathrm{~cm} \times$ 高 さ $2 \mathrm{~cm}$ ) 中に充填し，キャップで密封し， $10 \sim 30^{\circ} \mathrm{C}$ の 間の種々の温度で坐らせ，経時的に取り出した坐りゲル。 拈よびこれをさらに $90^{\circ} \mathrm{C} て ゙ 20$ 分間加熱して得た坐 り一加熱ゲルを調製し以下の実稌に供した。

かまぼこゲルの物性測定 坐り、および坐り一加熱ゲル の物性は、レオメーター（山電株式会社，レーオーナー RE-3305) を使用し, 坐りゲルの場合は直径 $5 \mathrm{~mm}$, 坐りー 加熱ゲルの場合は直径 $3 \mathrm{~mm}$ の円柱型プランジャーで, 破断強度 (g) と凹み (mm) t測定した。

SDS-尿素混合液による坐りゲルの可溶化と可溶化率 の測定 絸研した坐りゲル $0.4 \mathrm{~g}$ を精科し, $7.5 \mathrm{ml}$ の $2 \%$ SDS-8 м 尿素-2\% 2-メルカプトエタ/ール-20 mM Tris-

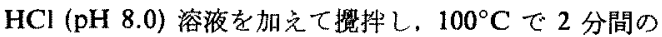
加熱後, 室温で約 20 時間筧拌し，可溶化した。可溶化 率の測定は，上記の可溶化溶滩を $20,000 \times \mathrm{g}$ て 30 分間 遠心分猚した上清液を水で 10 倍に希积し，その一定量

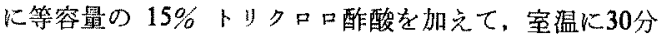
間以上放䈯し，遗心分㕍してタンパク質を沈殿させた。

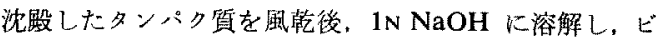
ウレット法により比色定舅した。そして塩ずり直後の肉 糊から可溶化したタンパク質量に対する相対值（\%)を 求めて可溶化㻭とした。

SDS-ポリアクリルアミトゲル電気泳動による坐りゲ ル中の Mf タンパク螅組成の検討 SDS-尿妻混合溶液に 可溶化した坐りゲル中のタンバク筫組成を Weber と Osborn ${ }^{197}$ の方法により，5\% ポリアクリルアミドゲル を用いた SDSーポリアクリルアミドゲル電気泳動 (SDS-
PAGE と略す) 法により定量した。泳動ゲル上のタンパ ク質の染色は Coomassie Brilliant Blue R を用いて行 い, 脱色は $50 \%$ ×夕ノール-7\% 酶酸溶液を用いて約 7 時間，続いて 7\% 䣫酸でダルの背景が透明化するまで行 った。泳動がル上の觔原線維タンック質成分の含量は, デンシトィーター（島津製作所，CS-910 型）を用いて 640 と $700 \mathrm{~nm}$ の吸光值の差として測定し, 各成分の染 色强度の合計值に対する相対染色强度（\%)で表した。

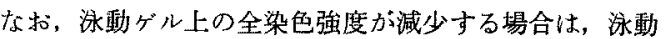
ゲル中に進入できないような大きなサイズのミオシン HC 多量体が生成したためとみなして，その量を計算で 求めた（この成分を以下 $\left(\mathbf{H C}_{\mathbf{n}^{\prime}}\right)^{\prime}$ と表す)。市た，坐りゲ ルが SDS-尿素混合溶液に溶解しない場合は，この成分 は特に巨大化したミオシン HC多量体と見なした（この 成分を( $\left(\mathrm{HC}_{\mathrm{n}}{ }^{\prime \prime}\right)$ と表与)。これらの成分量をも加えて全 染色強度を補正し、泳動ゲル上の各成分含量 $(\%)$ を求め た。

\section{結果および莟察}

冷谏すり身の Mf Ca-ATPase 全活性 ます 9\%の䌅 類と $0.3 \%$ の重合リン酸塩を含む通常の冷凍すり身（醥 準タイプ) と同じ量の榶類と重合リン酸塩の他に $0.1 \%$ のカルボン酸カルシウムと $0.1 \%$ の炭酸水素ナトリウム タ含む新タイプの冷凍すり身（新タイプと呼ぶ）の品質 を比べるため，加藤らが報じた方法りによって Mf CaATPase 全活性を測定し, その結果を Table 1 に示し た。これによると標蕉と新タイプの冷凍すり身の Mf Ca-ATPase 比活性值は，その活性を 0.1 および $0.5 \mathrm{M}$ $\mathrm{KCl}$ 存在下のいずれの条件下で揤定してもほとんど変

Table 1. Myofibrillar Ca-ATPase activity of standard and new types of frozen surimi

\begin{tabular}{|c|c|c|c|}
\hline & \multicolumn{3}{|c|}{$\begin{array}{l}\text { Mf Ca-ATPase Total Activity } \\
\mu \mathrm{mol} \mathrm{Pi} \text { release } / \text { min } 5 \mathrm{~g} \text { surimi }\end{array}$} \\
\hline \multirow{2}{*}{$\begin{array}{l}\text { Type of } \\
\text { surimi }\end{array}$} & \multicolumn{2}{|c|}{$\begin{array}{l}\mathrm{KCl}(\mathrm{M}) \text { for ATPase } \\
\text { assay }\end{array}$} & \multirow{2}{*}{$\begin{array}{l}\text { Mf protein } \\
\mathrm{mg} / 5 \mathrm{~g} \text { surimi }\end{array}$} \\
\hline & 0.5 & 0.1 & \\
\hline Standard & $\begin{array}{l}45.7 \\
(0.064)\end{array}$ & $\begin{array}{l}150 \\
(0.21)\end{array}$ & 714 \\
\hline New & $\begin{array}{l}46.8 \\
(0.065)\end{array}$ & $\begin{array}{l}150 \\
(0.21)\end{array}$ & 717 \\
\hline
\end{tabular}

The standard type of frozen surimi was prepared by the ordinary method, i.e. mixed with $5 \%$ sorbitol, $4 \%$ sucrose, and $0.3 \%$ Na-polyphosphate. A new type of frozen surimi was prepared basically in the same manner but was mixed with $5 \%$ sorbitol, $4 \%$ sucrose, $0.05 \%$ Ca-citrate, $0.05 \%$ Ca-lactate, $0.1 \%$ $\mathrm{NaHCO}$, and $0.3 \%$ Na-polyphosphate.

A quantitative determination of myofibrillar Ca-ATPase total activity was made by the method of N. Katoh (Ref. 7). Numbers in parenthesis represent the Ca-ATPase specific activity in $\mu \mathrm{mol} \mathrm{Pi}$ release $/ \mathrm{min} \cdot \mathrm{mg}$ of protein. 
わらなかった。また，Mf タンパク質量もはぼ同じです るから Mf Ca-ATPase 全活性も近似している。したが って、これら 2 種の泠湅すり身は，その主要成分である ミオシンに閏しては，量的ばかりでなく，筫的にも差異
がないと判断される。

冷凍すり身の坐りゲル形成能 標準タイブと新タイプ の泠涷すり身を塩ずりした肉糊を $10,20,25$ ，扣よび 30

${ }^{\circ} \mathrm{C}$ で 24 時間にわたって坐らせた坐りゲルと，これをさ

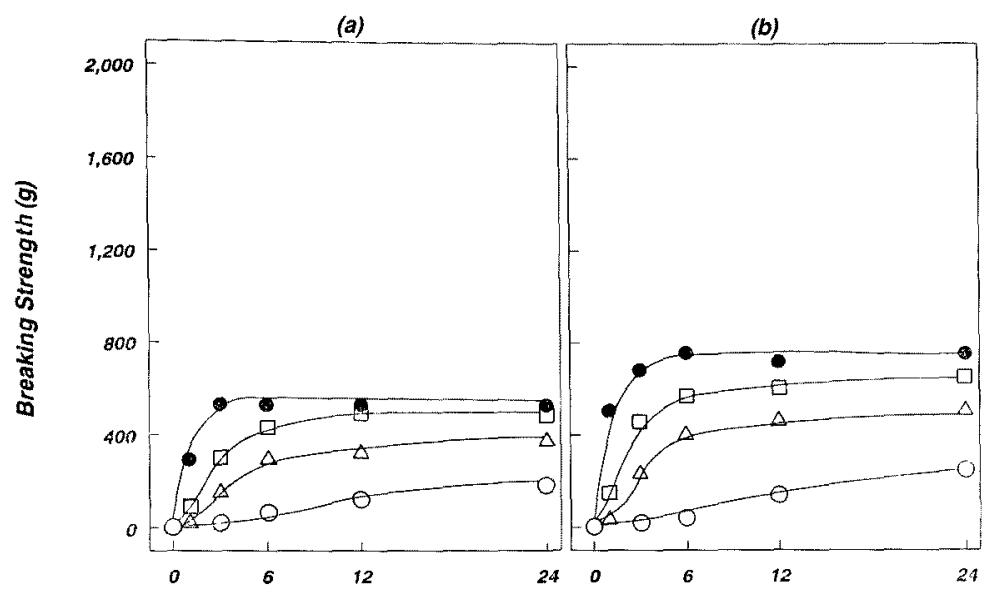

Setting Time (h)

(c)

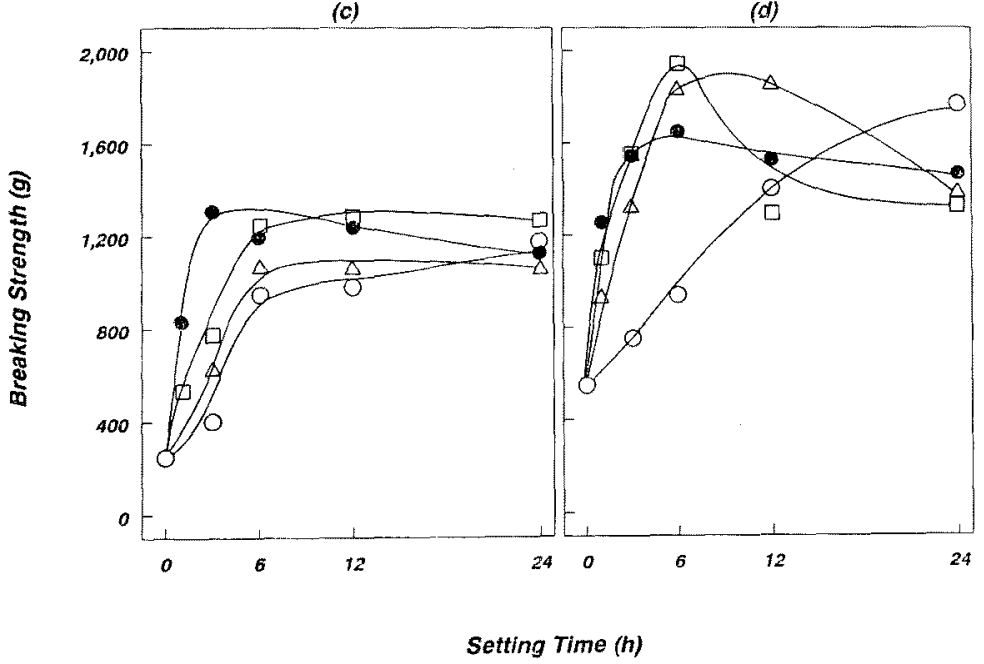

Fig. 1. Change in breaking strength of gels formed by setting and setting-heating from saltground meat.

The standard type and a new type of frozen surimi as in Table 1 were employed in this assay. Surimi was chopped with $2.5 \% \mathrm{NaCl}$ in a chilled speed cutter (National MK K7) for $5 \mathrm{~min}$ at $10^{\circ} \mathrm{C}$ or below. The salt-ground meat was stuffed into a plastic vessel with a cover and incubated at $10,20,25$, or $30^{\circ} \mathrm{C}$ to prepare a setting gel (A). It was subsequently heated at $90^{\circ} \mathrm{C}$ for $20 \mathrm{~min}$ to prepare a setting-heating gel (B). After cooling the gels with ice-water for $30 \mathrm{~min}$, breaking strength $(\mathrm{g})$ was measured with a rheometer equipped with a $\phi 5 \mathrm{~mm}$ plunger for the setting gel and a $\phi 3 \mathrm{~mm}$ plunger for the settingheating gel.

$(a, c)$ Standard type, (b, d) new type.

Temperatures for setting were $10(O), 20(\Delta), 25(\square)$, and $30^{\circ} \mathrm{C}(\bullet)$. 
(a)

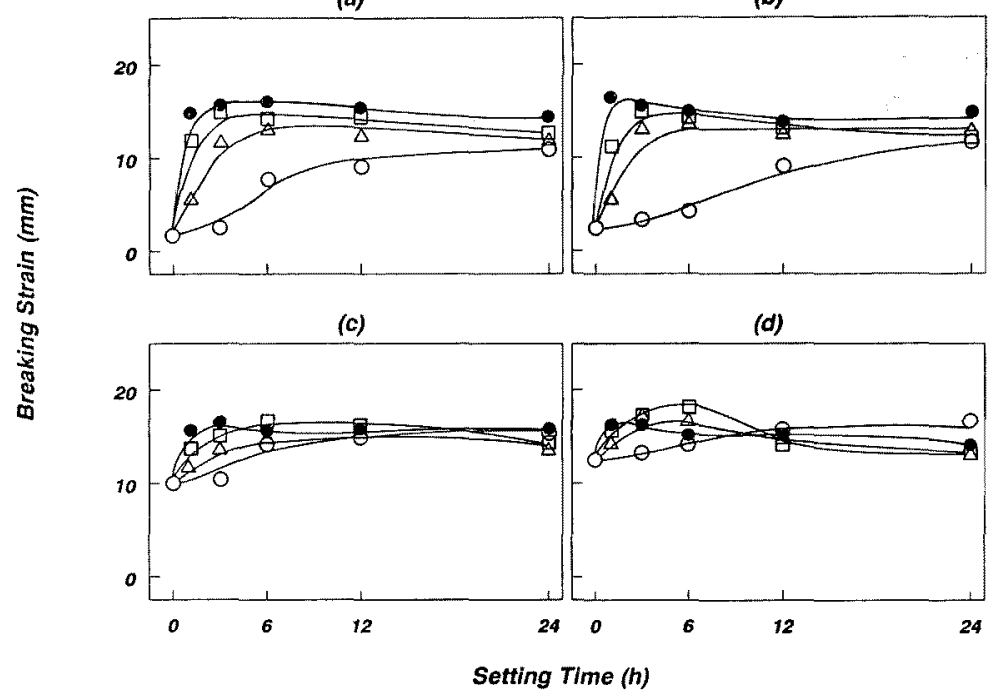

Fig. 2. Change in breaking strain of gels formed by setting and setting-heating from saltground meat.

From two types of frozen surimi, a setting gel (a, b) and a setting-heating gel $(c, d)$ were prepared, and the breaking strain of the gels was measured as in Fig. 1.

(a, c) Standard type, (b, d) new type.

Temperatures for setting were $10(\mathrm{O}), 20(\Delta), 25(\square)$, and $30^{\circ} \mathrm{C}(\bullet)$.

らに $90^{\circ} \mathrm{C} て ゙ 30$ 分間加熱した坐りー加熱ゲルの破断強 度を Fig. 1 (A, B) に、凹みを Fig. 2 に示した。Fig. 1 Kよると，坐りダル (a, b) 扎よび坐り一加熱ゲル (c， d）破断強度は坐りの初期に急激に增加し，ほぼ 6 時間 後に最大值に達すること，末た温度が高い注ど破断強度 の増加の速度と度合いが大きくなる傾向を示すこと，さ らに，90 $\mathrm{C}$ 加熱に上って大幅な破断強度の增加が起こ り、いわゆる坐りの効果が発揮されることなどが認めら れだ。ただ，同じ条件下で比較すると，新タイプのす り身から作った坐りゲルおよび坐り一加熱ゲルは標準タ イプから作ったすのより高い破断強度に達与ること， さら火新タイプのすり身から作った坐り一加熱ダルの破

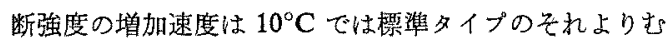

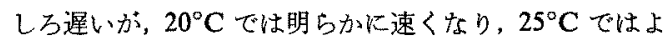
り速やかに最大値に逵した後減少すること、しかし $30^{\circ} \mathrm{C}$ ではむしる增加しにくくなることなどが示されている。

次に Fig. 2 によると，坐りゲルと坐り一加熱ゲルの山 又は，破断強度の場合之同様に，坐り初期に大きく増加 して最大値に趭すること, 温度が高い汪ど速やが增加 する偩问を示すこと，末た $90^{\circ} \mathrm{C}$ で加熱すると僅かであ るがいずれる增加し，坐りの效果が辡められることなど か゚示されている。な乱，新タイプの冷谏すり身から作っ た肉怙の凹み隹，同し条件下で標準タイプのすり身から 作ったものよりも，僅かであるが高い值となるが，20ㄷ
以上では一旦増加した後やや減少する傾向を示す点で は, 破断強度の変化と似ている。

坐りゲルの SDS-尿素混合液による可溶化 標準タイ プと新タイプのすり身から作っだ坐りゲルの SDS-尿素 混合液に対する可溶化率を測定し，その結果をFig. 3 に 示した。これによると，標準タイプのすり身から作った

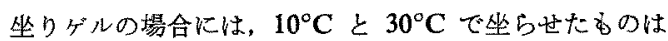

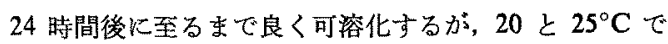
坐らせたるのは坐りが 12 時間以上に及ぶと不溶化し, 可溶化率が減少する傾向を示した。これに対して新タイ プのすり身から作った坐りゲルでは，10ㄷ で坐らせた もの性 24 㭙間後まで良〈可溶化するるのの $20^{\circ} \mathrm{C}$ で坐 らせたものは 6 時間後から，また $25^{\circ} \mathrm{C}$ の場合では 3 時 間後から可溶化率が低下することが示され，ミオシン重 鎖の多量化反応が進行していることを強く示唆した。し

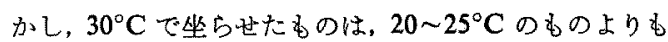
むしろ可溶化し易く，6時間以後に不溶化したが，その 程度は $25^{\circ} \mathrm{C}$ のものより少なかった。すなわち、どち らのすり身の場合であ，坐りゲルの可溶化率の低下は, $10 \sim 25^{\circ} \mathrm{C}$ の間で漓温になるにつれて大きく起こった が, $30^{\circ} \mathrm{C}$ で $25^{\circ} \mathrm{C}$ のbのより可溶化し易く, さらに，

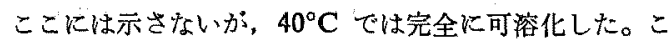
の剚奏は $25^{\circ} \mathrm{C}$ 以下と $30^{\circ} \mathrm{C}$ 以上で形成される坐りゲル が留的に異なる棈造体であることを示焧している。 


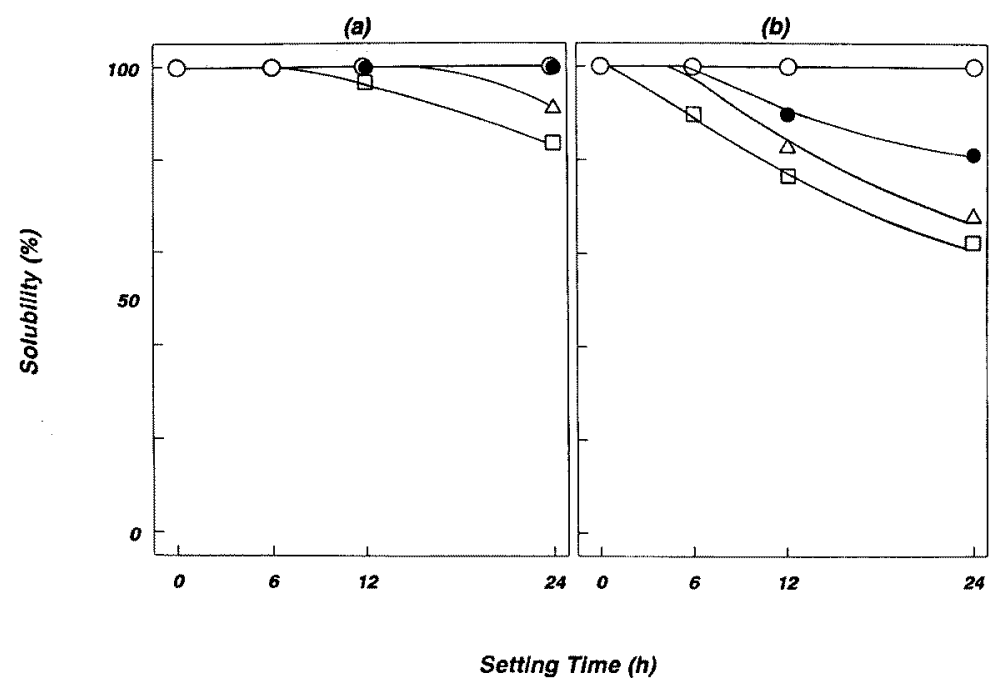

Fig. 3. Change in solubility of myofibrillar protein of salt-ground meat into an SDS-ureamercaptoethanol medium during setting.

The setting of the salt-ground meat was made as in Fig. 1. The product $(0.4 \mathrm{~g})$ was solubilized with $7.5 \mathrm{ml}$ of $2 \%$ SDS- $8 \mathrm{M}$ urea-2\% mercaptoethanol-20 mM Tris- $\mathrm{HCl}(\mathrm{pH} 8.0$ ) buffer at $100^{\circ} \mathrm{C}$ for $2 \mathrm{~min}$, and then was stirred for $24 \mathrm{~h}$ at room temperature. After centrifugation at $20,000 \times \mathrm{g}$ for $30 \mathrm{~min}$, the amount of soluble protein in the supernatant was determined by the biuret method, and solubility was expressed as a relative value (\%) taking the amount of soluble protein of each meat before the setting as $100 \%$.

(a) Standard type, (b) new type.

Temperatures for setting were $10(0), 20(\Delta), 25(\square)$, and $30^{\circ} \mathrm{C}(\bullet)$.

お゙，坐りゲルの可溶化率は坐りー加熱ゲルのそれと同じ であることが既に知られている。象

坐りゲル中の Mf タンパク䨘サフユニット組成 次以 Fig. 1〜3 に示した坐りゲル中の Mf タンパク質サブニ ニット組成を，沼倉らが先に提案した SDS-PAGEを用

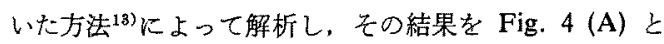
(B) に示した。亦ず Fig. 4 (A) には，標準タイプのすり 身から作った肉糊を $10^{\circ} \mathrm{C}(\mathrm{a}, \mathrm{b}), 20^{\circ} \mathrm{C}(\mathrm{c}, \mathrm{d}), 25^{\circ} \mathrm{C}(\mathrm{e}$, $\mathrm{f})$, そして $30^{\circ} \mathrm{C}(\mathrm{g}, \mathrm{h})$ て坐ら咕て得た坐りゲル中のミた シン $\mathrm{HC}$ と多の多量体成分である $\left(\mathrm{HC}_{\mathrm{n}}\right),\left(\mathrm{HC}_{\mathrm{n}^{\prime}}\right)$ 执よ び $\left(\mathrm{HC}_{\mathrm{n}}{ }^{\prime \prime}\right)$ を(a), (c), (e), (g)K、またアクチン(トロポ ミオシンを含む), $\mathrm{X}_{1}$ 成分 (ミオシン $\mathrm{HC}$ とアクチンの 中間に泳動する未同定成分)，扰よび $X_{2}$ 成分 (アクチン よりも泳動し易い未同定成分) を(b)，(d)，(f)，(h) に示 した。これによると，いずれの温度で坐らせた場合も， その初期にミオンン HCが急激に減少してその後, 最小 值に達するが，それに伴って初めに $\left(\mathrm{HC}_{\mathrm{n}}\right)$ が、続いて $\left(\mathrm{HC}_{\mathrm{n}^{\prime}}\right)$ 加增加した後減少し, 最後に $\left(\mathrm{HC}_{\mathrm{n}^{\prime \prime}}\right)$ が增加す るが、フクチン成分と $\mathrm{X}_{1}$ 枕よび $\mathrm{X}_{2}$ 成分は忹とんど变 化しないことが示されている。きた，温度が高い后ど， ミオシン $\mathrm{HC}$ の多量化反応が速く進み, $\left(\mathrm{HC}_{\mathrm{n}}\right),\left(\mathrm{HC}_{\mathrm{n}}{ }^{\prime}\right)$ および $\left(\mathrm{HC}_{\mathrm{n}^{\prime \prime}}\right)$ が生成する密での時間が短く，かり生成

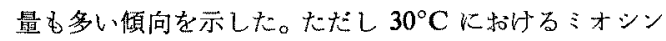
$\mathrm{HC}$ の多量体の生成量は $25^{\circ} \mathrm{C}$ の基合上り必少ないが， この傾向は $40^{\circ} \mathrm{C}$ 以上になるとより低下し（ここには困 示しない),このことは拈そらく $30^{\circ} \mathrm{C}$ 以上のときの坐り 反応の特徵の1つであるように思われる。

一方，Fig. 4 (B) には，新タイプのすり身から作った 肉糊を, $10^{\circ} \mathrm{C}(\mathrm{a}, \mathrm{b}), 20^{\circ} \mathrm{C}(\mathrm{c}, \mathrm{d}), 25^{\circ} \mathrm{C}(\mathrm{e}, \mathrm{f}), 30^{\circ} \mathrm{C}$ $(\mathrm{g}, \mathrm{h})$ で加熱したときの坐りゲル中の Mf タンパ質サ ブニニット成分の変化を示した。これによると, 各成分 の変化の傾向は，標準タイプのすり身を使用した場合 (A) と似て和り，温度が高いはぼミオシン HC の減少は 大きく, $\left(\mathrm{HC}_{\mathrm{n}^{\prime \prime}}\right)$ が生成する反応が速くなった。ただし，30ㄷ は, $25^{\circ} \mathrm{C}$ の場合よりも $\left(\mathrm{HC}_{\mathrm{n}}\right)$ と $\left(\mathrm{HC}_{\mathrm{n}^{\prime}}\right)$ の生成は速い が, $\left(\mathrm{HC}_{\mathbf{n}^{\prime \prime}}\right)$ の生成はかなり濢くなっている。これる $30^{\circ} \mathrm{C}$ 以上の坐りに扎いて認められる糸化の特徽であるかむ

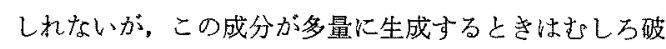
断強度が減少する傾向を示した。一方, アクチン成分,

$\mathrm{X}_{1}$ 扣よび $\mathrm{X}_{2}$ 成分には大きな変化が認められなかった。 新タイプのすり身から作った坐りダルを，標準タイブ のそれと比べると, 前者では上記の一連の变化が速く起 こるのが特徴であり，特に $20 \sim 30^{\circ} \mathrm{C}$ に和けるミオンン 
$\mathrm{HC}$ の減少，それに伴う $\left(\mathrm{HC}_{\mathrm{n}}\right)$ と $\left(\mathrm{HC}_{\mathrm{n}^{\prime}}\right)$ の生成，そ の減少に伴う $\left(\mathrm{HC}_{\mathrm{n}}{ }^{\prime \prime}\right)$ の生成が起こる時間は, いずれも かなり短く、ミオシン HC の多量化反応が著しく速くな っていた。

また，塩ずり直後の肉糊中のミオシン HC 含量は，塩 ずり前のすり身に比べ，標準タイプのすり身を用いた場 合でも塩ずり中にやや城少 $(2 \sim 3 \%$ ほど)して，ミオシ ン HCD多量体を形成していると推定されるが、新タイ プのすり身の肉糊の方がさらに5\%秪く，代わって $\left(\mathrm{HC}_{\mathbf{n}}\right)$ 量が多くなっている。したがって, 新タイプのす り身に添加されたカルボン酸カルシウムや炭酸水素ナト リウムのいずれかの成分が，塩ずり中にも肉糊中のミ才 シン HCの多量化反応を促進し，破断強度などゲル物性 に寄与していることは明らかである。

次に Fig. 4 K示した坐りゲル中の Mf タンバク質の サブニニットの変化は，沼倉らの報告泉と同様に，坐り ゲルおよび坐りー加熱のゲル物性 (Fig. 1B) の变化と良 く対応している。まず標準タイプのすり身から作った肉 糊を坐らせるとミオンン HC が減ってその多量体が生 成するが、これはゲル物性（特に破断强度）の变化と関 連し，たとえば温度の高いはらが破断強度がより速く増
加するが，これは $\left(\mathbf{H C}_{\mathbf{n}}\right)$ の增加速度が大きくなるのと 対応している。去，新タイプのすり身から作った肉糊 の昜合同じく $\left(\mathrm{HC}_{\mathrm{n}}\right)$ 生成の速さが，その破断強度 の增加速度に対応し，一般に温度が高いほうが，雨者の 增加が速いことを示している。ただし，坐り一加熱ゲル の破断強度の最大值はもしろ $\left(\mathrm{HC}_{\mathbf{n}^{\prime}}\right)$ の生成量と対応し て扣り，その量が多いほど高い值を示す傾向があり，こ れは，標準タイプのすり身から作った場合も同じであっ た。亦た一旦增加した破断強度がその後減少するのは $\left(\mathrm{HC}_{\mathbf{n}^{\prime \prime}}\right)$ が生成增加するのと良く対応し，ミオシン $\mathbf{H C}$ の多量化反応が進行してその多量体が巨大化し過ぎこ とがゲル物性の少化につながると推定されている。す なわら，一旦增加した破断強度が減少するのは，20 Cて は 12 時間後, $25^{\circ} \mathrm{C}$ では 6 時間後であるが、いずれる ある程度の量の $\left(\mathrm{HC}_{\mathrm{n}}{ }^{\prime \prime}\right)$ が生成したときである。また， $10^{\circ} \mathrm{C}$ では 24 時間後になっても $\left(\mathrm{HC}_{\mathrm{n}^{\prime \prime}}\right)$ 恃生成せず $\left(\mathrm{HC}_{\mathbf{n}^{\prime}}\right)$ の生成量も僅かであるが，実際にこの坐り一加熱 ゲルの破断強度は一方的に增加する段階にあり最大值 には達していない。この対応は，標準タイプのすり身 を使用した坐りー加熱ゲルの場合にも見られ，ここでは $\left(\mathrm{HC}_{\mathbf{n}^{\prime \prime}}\right)$ は生成しないか, 生成してもその量は少ないが,
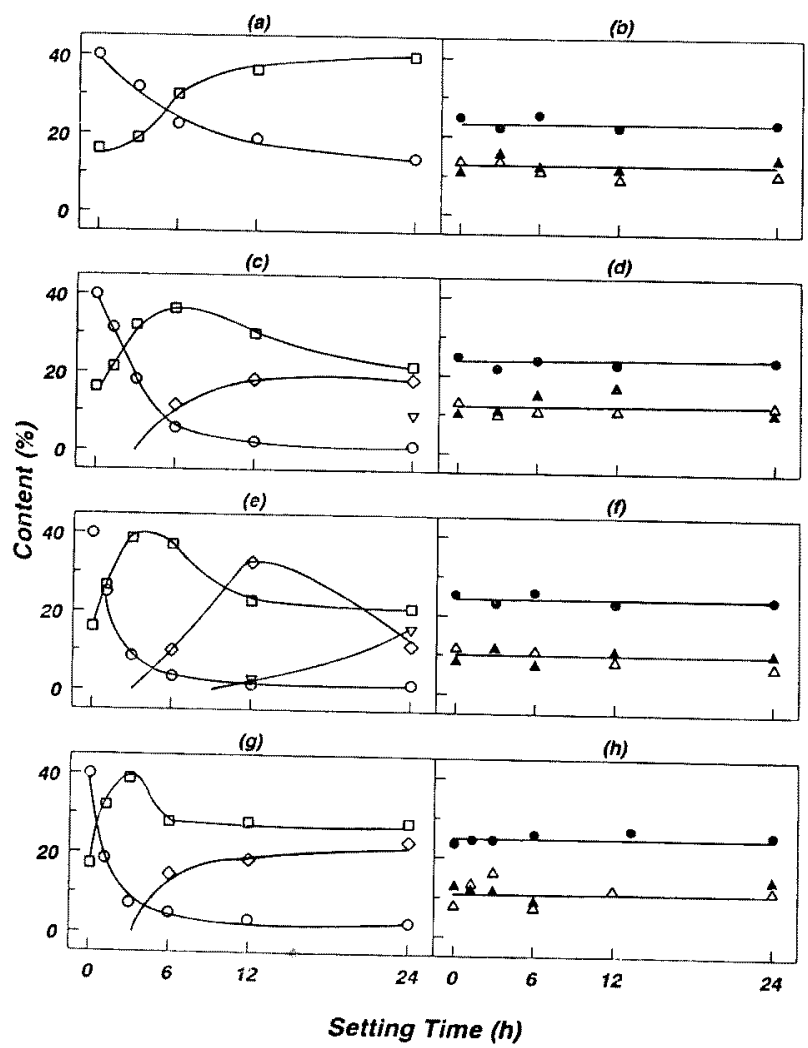

Fig. 4 (A) 


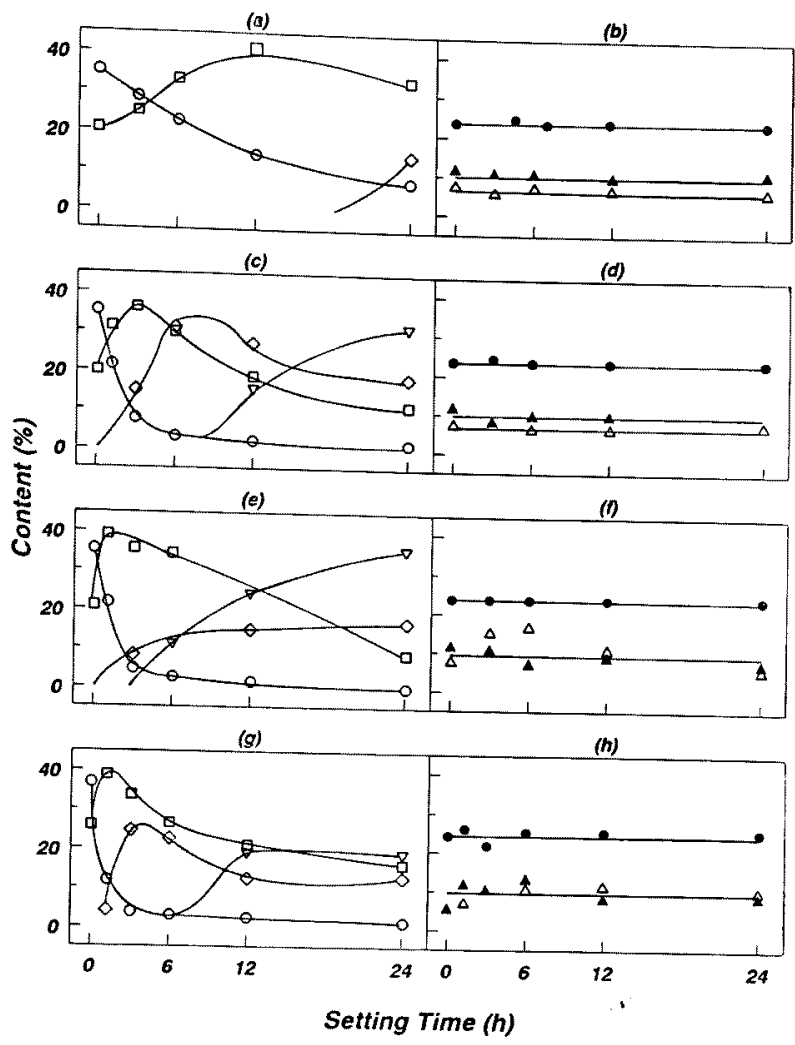

Fig. 4 (B)

Fig. 4. Change in subunit composition of myofibrillar protein of salt-ground meat during setting.

From two types of surimi, the setting gels were prepared as in Fig. 1. The setting gels were solubilized into an SDS-urea medium as in Fig. 3. The soluble protein $(20 \mu \mathrm{g})$ was applied to SDS-polyacrylamide gel electrophoresis using a $5 \%$ polyacrylamide gel. The protein on the gel rod was stained with Coomassie Brilliant Blue R. The content of each protein component was estimated by quantitative densitometetry and expressed as relative intensity (\%), taking the sum of densities of all components as $100 \%$. Components too large to migrate into the gel rod and those insoluble into the SDS-urea buffer were added to the total content.

(O): Myosin heavy chain (HC).

(•): Actin + tropomyosin (A+TM).

$(\Delta)$ : Components migrating between $\mathrm{HC}$ and actin $\left(\mathrm{X}_{1}\right)$.

(A): Components migrating faster than tropomyosin $\left(\mathrm{X}_{2}\right)$.

(ㅁ): Cross-linked myosin heave chain $\left(\mathrm{HC}_{\mathrm{n}}\right)$, migrating into $5 \%$ polyacrylamide gel.

( $)$ : Components corresponding to cross-linked myosin heavy chain too large to migrate into a $5 \%$ polyacrylamide gel $\left(\mathrm{HC}_{\mathrm{n}^{\prime}}\right)$.

$(\nabla)$ : Components corresponding to cross-linked myosin heavy chain insolubilized into the SDS-urea buffer $\left(\mathrm{HC}_{\mathrm{n}^{\prime \prime}}\right)$.

(A) Standard type, (B) new type.

Temperatures for the setting were $10(a, b), 20(c, d), 25(e, f)$, and $30^{\circ} \mathrm{C}(\mathrm{g}, \mathrm{h})$.

このとき破断強度は単調に增加するかまだはとの值を保

っている。

以上述べたよらに，膘準タイブと新タイブの冷凍すり

身から作った 2 種の肉糊の坐りゲル形成能と，それに伴
らミォンンHCの多量化能は明らかに相避している。ま た，坐りゲルと坐りー加熱ゲル中の Mf タンパク質のサ ブュニット組成はほとんど同じであり，85 90 ${ }^{\circ} \mathrm{C}, 20$ 分 の加熱中に変化しないことが既に知られている。 
がって新タイプのすり身から得た坐り一加熱ゲルのゲル 物性がすり身中の添加物によって著しく増強されるの は, $10 \sim 25^{\circ} \mathrm{C}$ の低温下の坐り過程で扰こるミオシン $\mathrm{HC}$ の多量化反応に対してカルボン酸カルシウムと炭酸水素 ナトリウムが影響を及ぼした結果であると判断すること

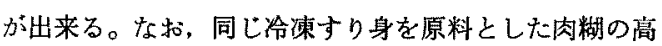
温下 $\left(40^{\circ} \mathrm{C}\right.$ 以上) に亦けるゲル形成能は現在検討中です るが，結果は別に報ずる。

本研究の結果は，冷湅すり身に添加される各種の添加 物はすり身の凍結賠蔵に扣ける品質保持4,15) ばかりでな く，これを原料として製造するかまばこゲルの品質に対 しても，肉糊の坐りの工程で起こる各種の反応に制御を 介して，大きな影繁を及ぼす可能性があることを示して いる。これは桾類*1や重合リン酸塩*2 の昜合でも同じで あることが知られている。また，本夹験では煻としてり ルビトールと砂糖，末たカルボン酸カルシウムとしては クェン酸カルシウムと乳酸カルシウム，その他に炭酸水 素ナトリウムを添加しているので，この中のどの成分が すり身の品筫改良のために大きな协力を発揮するかを確 定する研究が必要である。たたし，含まれている糖類の 種類と量は同じであり，また，新タイプのすり身の $\mathrm{pH}$

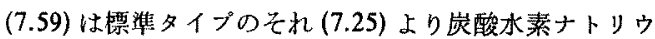
ムの添加により，高い值であるものの，この籍国ではゲ ル形成能やミオシン HC の多量化能に大きく影罂しな いと考えられる12)ことから、特そらくはカルボン酸カル シウムが上記したゲル形成能やミオシン HC の多量化 能の变化熶る関与しているものと考劣ている。
文献

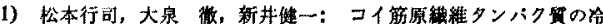

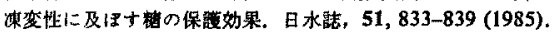

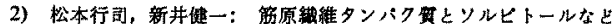

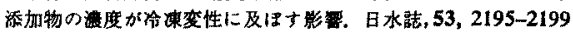
(1987).

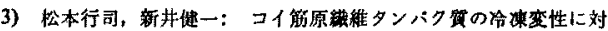

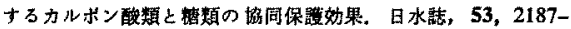
2193 (1987).

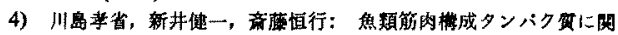
ナる研究—X スケトウタラ命䂺ナり身中のアクトミオシン合 胃について. 日水声, 39,525-532 (1973).

5) 佐伯宏燩，尾崎弘忠，野中渞夫，関伸夫，新井健一：スケ

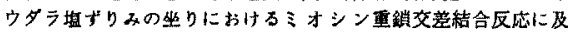

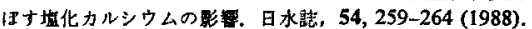

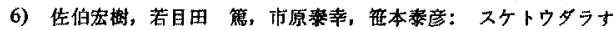

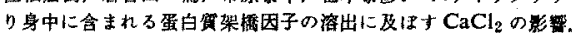
日水誌，55, 1867 (1989).

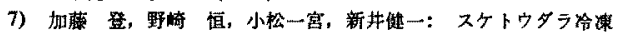
ナり身の一新品判定法. 冷淉すり身の穊原線維 ATPase 活性: とかま涩こ形成能の成係. 目水誌, 45, 1027-1032 (1989).

8）沼會忠弘，木村郁夫，豊田恭平，藤田孝夫：スケトウダラ内蝴 の坐りに伴うケル強度とミオシン重鎖の变化の温度伎存性。回 水誌, 56, 2035-2043 (1990).

9) A. G. Gornall, C. J. Bardawill, and M. M. David: Determination of serum proteins by means of the biuret reaction. J. Biol. Chem., 177, 751-766 (1949).

10) G. Gomori: A modification of the colorimeteric phosphorus determination for use with the photoelectric colorimeter. J. Lab. Clin. Med., 27, 955-960 (1942)

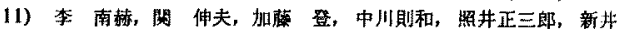
䛧一：イトヨリダイの肉糊のゲル形成能とミオシン荲銷の穸奎 結合能. 日水詰, 56, 329-336 (1990).

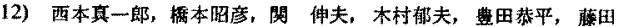
孝夫，新井健一：スケトウタラ肉糊の坐りれに起るミオンン重

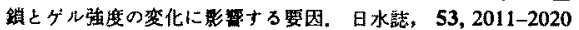
(1987).

13) $\mathrm{K}$ Weber and $\mathrm{M}$. Osborn: Reliability of molecular weight determinations by dodecyl sulfate-polyacrylamidegel electrophoresis. J. Biol. Chem., 244, 4406-4412 (1969).

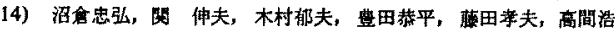
葴，新井健一：坐りによる内糊のゲル北成とミオシンの交差結 合反心. 日水詰，51, 1559-1565 (1985).

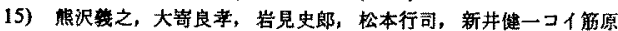

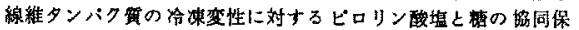

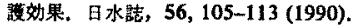

*1 新井健一，関 伸夫：㗁和 62 年度魚介類有效栄養成分利用技街研究成果の概要，1987，p. 1042 .

*2 松川雅仁, 新井梴一; 平成 2 年度日本水应学会秋季大会請演要旨集 p. 221 . (日水誌投稿受理) 